\title{
AFLATOXIGENIC ASPERGILLUS FLAVUS AND ASPERGILLUS PARASITICUS STRAINS IN HUNGARIAN MAIZE FIELDS
}

\author{
FlóRA SEBÖK*, CSABA DOBOLYI, DÓRA ZÁGONI, ANITA RiSA, CSILla \\ Krifaton, MÁtyÁs Hartman, MÁtyÁs CsERHÁti, SÁNDOR SZOBOsZlay and \\ BALÁZS KRISZT \\ Department of Environmental Safety and Ecotoxicology, \\ Szent István University, Gödöllö, Hungary
}

(Received: 6 January 2016; accepted: 26 August 2016)

\begin{abstract}
Due to the climate change, aflatoxigenic Aspergillus species and strains have appeared in several European countries, contaminating different agricultural commodities with aflatoxin. Our aim was to screen the presence of aflatoxigenic fungi in maize fields throughout the seven geographic regions of Hungary. Fungi belonging to Aspergillus section Flavi were isolated in the ratio of $26.9 \%$ and $42.3 \%$ from soil and maize samples in 2013, and these ratios decreased to $16.1 \%$ and $34.7 \%$ in 2014 . Based on morphological characteristics and the sequence analysis of the partial calmodulin gene, all isolates proved to be Aspergillus flavus, except four strains, which were identified as Aspergillus parasiticus. About half of the A. flavus strains and all the A. parasiticus strains were able to synthesize aflatoxins. Aflatoxigenic Aspergillus strains were isolated from all the seven regions of Hungary. A. parasiticus strains were found in the soil of the regions Southern Great Plain and Southern Transdanubia and in a maize sample of the region Western Transdanubia. In spite of the fact that aflatoxins have rarely been detected in feeds and foods in Hungary, aflatoxigenic A. flavus and A. parasiticus strains are present in the maize culture throughout Hungary posing a potential threat to food safety.
\end{abstract}

Keywords: Aspergillus flavus, Aspergillus parasiticus, SOS chromotest, aflatoxin biosynthesis genes

\section{Introduction}

The genus Aspergillus is a quite diverse group including 339 species belonging to 19 sections based on partial calmodulin gene sequences [1]. Aspergillus section Flavi contains species (e.g., Aspergillus oryzae, Aspergillus

*Corresponding author; E-mail: sebok.flora@gmail.com 
sojae, and Aspergillus tamarii) used in the food industry as well as mycotoxinproducing species (Aspergillus flavus and Aspergillus parasiticus) [2-5]. Mycotoxins are secondary metabolites produced by filamentous fungi having acute or chronic toxic effect on humans and animals. One of the most important groups of mycotoxins are aflatoxins, which were discovered in the United Kingdom in the 1960 s when they were identified as the causative agent of "turkey X" disease. Investigation cleared that the feed consumed by turkeys contained A. flavus contaminated peanut with a South American origin [6]. The toxin was named after its producer (Aspergillus flavus toxin), and based on the color of the intense fluorescence in ultraviolet light aflatoxin B (AFB) (Blue) and aflatoxin G (AFG) (Greenish yellow) can be distinguished [7]. $\mathrm{AFB}_{1}$ and $\mathrm{AFB}_{2}$ are mainly produced by $A$. flavus and $A$. parasiticus, but the latter produces $\mathrm{AFG}_{1}$ and $\mathrm{AFG}_{2}$ as well [8]. Among these toxins, $\mathrm{AFB}_{1}$ is the most toxic, causing carcinogenic, teratogenic, and immunosuppressive effects, and it was classified in Group 1 by the International Agency for Research on Cancer [9].

Generally, A. flavus and A. parasiticus are unspecialized saprophytes; these fungi can degrade biopolymers as cellulose, pectin, lignin, and lipids in soil with their catabolic enzymes [10-13]. They have been isolated from the soil of different biomes (forest, grassland, wetland, and desert) [14]; however, it was found that cultivated soils contain higher proportion of A. flavus than natural habitats [15]. Previously, it was thought that only tropical and subtropical regions are favorable for the aflatoxin-producing fungi [5], but due to the climate change these fungi found their niche also in Europe. Since the first Italian aflatoxin outbreak (2003), aflatoxin contamination has not confined only to imported commodities and aflatoxin and/or the producing fungi have been detected in the agricultural commodities of several European countries [16-21].

In Hungary, Richard et al. examined first the mycotoxin-producing ability of the A. flavus isolates obtained from various sources (e.g., corn, soya, and wheat) [22]. They found that none of the 32 isolates was able to produce $\mathrm{AFB}_{1}$. Borbély et al. examined 83 cereal samples from 2005 to 2008 for aflatoxin content and three samples proved to be over the allowable level [23]. Dobolyi et al. collected 104 maize samples from different maize growing regions in Hungary between 2009 and 2010. A. Alavus was isolated from $63.5 \%$ of the samples and $18.8 \%$ of these isolates were found to be able to produce aflatoxins above $5 \mu \mathrm{g} / \mathrm{kg}$ on maize kernels. It should be noticed that 43 of the tested 69 strains also produced $\mathrm{AFB}_{1}$ under the level of $5 \mu \mathrm{g} / \mathrm{kg}$ official EU limit [24]. Tóth et al. investigated the occurrence of Aspergillus species and their mycotoxins on maize in Hungary between 2010 and 2011. Several potentially aflatoxigenic 
A. flavus strains were isolated but none of the maize samples contained aflatoxins [25].

Our aim was to study the occurrence of aflatoxigenic Aspergillus section Flavi in maize fields throughout Hungary (a) with the screening for the presence of the fungi in soil, as a reservoir for the infection of crops, and maize kernels and (b) with the analysis of the aflatoxin-producing ability of the isolated strains.

\section{Experimental Analysis}

Sampling soils and maize kernels

Both soil and ear samples were collected from 196 maize fields of Hungary in the period of July 2013 to October 2014. Number of the samples per region is presented in Table I. Ten ears were collected from each maize field and approximately $100 \mathrm{~g}$ soil samples (consisted of five subsamples) were taken from the upper $1 \mathrm{~cm}$ layer of the soil surface with a sterile trowel into clean ziplock bags. Samples were stored at $4{ }^{\circ} \mathrm{C}$ until the analysis.

\section{Fungal isolates identification}

Ears were shredded and the surface of 20 kernels per sample was disinfected, then aseptically cut into halves and placed on culture media with its cut surface (five pieces per Petri dish). Soil subsamples were mixed in the bag, and then $10 \mathrm{~g}$ of each soil sample were suspended in $90 \mathrm{ml}$ of sterile distilled water. Soil suspensions were bath sonicated at $37 \mathrm{kHz}$ for $5 \mathrm{~min}$ to disperse soil aggregates and vortexed for $5 \mathrm{~s}$ before aliquots of $100 \mu \mathrm{l}$ was spread (in triplicate) on Petri dishes with pentachloronitrobenzene-rose bengal-glycerol agar [26]. This media was originally introduced for culturing Fusaria from environment; however, it was also found to be suitable for obtaining isolates of Aspergillus section Flavi [24]. The inoculated plates were incubated at $37^{\circ} \mathrm{C}$ for 5 days. Typical green colonies were transferred to malt extract agar and incubated at $26^{\circ} \mathrm{C}$ for further morphological characterization [1]. Beside the classical identification, the partial calmodulin gene sequence was analyzed as follows. DNA was extracted using the Masterpure ${ }^{\mathrm{TM}}$ yeast DNA purification kit (Epicentre Biotechnologies, USA) according to the instructions of the 
manufacturer. Partial calmodulin gene was amplified using primers cmd5 and cmd6 [27]. The amplified DNA fragments were purified by NucleoSpin ${ }^{\circledR}$ Gel and PCR Clean-up kit (Macherey-Nagel, Germany). The purified polymerase chain reaction (PCR) products were used in sequencing reactions using a BigDye Terminator v3.1 Cycle Sequencing Kit (Applied Biosystems, USA). Sequencing was performed on an ABI Prism 310 Genetic Analyzer (Applied Biosystems, USA). Sequences were compared to the NCBI GenBank Sequence Database (http://www.ncbi.nlm.nih.gov). The representative strains of Aspergillus section Flavi were maintained in $20 \%(\mathrm{w} / \mathrm{w})$ glycerol solution at $-80{ }^{\circ} \mathrm{C}$ in our culture collection for further examinations.

\section{Detection of aflatoxin-producing ability of isolated strains}

$\mathrm{AFB}_{1}$-producing ability of the strains was studied with the presence of two structure genes (nor-1 and omt-1) and a regulator gene (aflR) involved in the aflatoxin biosynthesis, and with the measurement of the genotoxic effect of $\mathrm{AFB}_{1}$ produced on maize kernels by the strains. The nor-1, omt-1, and aflR genes were amplified according to Erami et al. [28]. PCR products were visualized on ethidium bromide-stained 1\% agarose gels.

Twenty-five grams of dry forage maize were soaked in water for $1 \mathrm{~h}$, then poured off the water, and autoclaved at $121{ }^{\circ} \mathrm{C}$ for $15 \mathrm{~min}$ two consecutive days. The sterilized maize kernels were inoculated with conidium suspensions $\left(1 \mathrm{ml}, 10^{6} \mathrm{CFU} / \mathrm{ml}\right)$ of each strain previously grown on potato dextrose agar medium for 7 days. The inoculated maize was incubated for 21 days at $26^{\circ} \mathrm{C}$. The moldy kernel samples were autoclaved at $100{ }^{\circ} \mathrm{C}$ for $30 \mathrm{~min}$ after incubation and grounded using mortar and pestle. Aliquot of $1 \mathrm{~g}$ of the grounded kernels was placed in a test tube and $4 \mathrm{ml}$ of $70 \%$ methanol was added. The content of the test tube was mixed for $2 \mathrm{~h}$ on a reciprocating shaker $(180 \mathrm{rpm})$ and then centrifuged at $14,000 \mathrm{rpm}$ for $10 \mathrm{~min}$. The genotoxic effect of aflatoxin was detected from the supernatants with SOS chromotest ${ }^{\mathrm{TM}}$ kit (Environmental Bio-detection Products Inc., Ontario, Canada) according to the instructions of the manufacturer. Induction factor (IF) was calculated according to the report of Krifaton et al. [29]. Samples with 1.5 or higher IF were considered genotoxic.

The concentration of aflatoxins $\left(B_{1}, B_{2}, G_{1}\right.$, and $\left.G_{2}\right)$ was also measured in the case of seven $A$. flavus strains having different IF values (1.51-4.49) and all the $A$. parasiticus strains with high-performance liquid chromatography (HPLC) (AflaTest WB, VICAM, USA) by an accredited laboratory. 


\section{Results}

\section{Aspergillus section Flavi in maize fields of Hungary}

Propagula of the fungi belonging to Aspergillus section Flavi were found in $21(26.9 \%)$ soil samples and $33(42.3 \%)$ maize samples from the total of 78 maize fields throughout Hungary in 2013. Both sample types (soil and maize) of 11 sites proved to be positive for the presence of the fungi. Soil samples of further 10 and maize samples of further 22 sites contained these molds. In the case of 35 maize fields, no potentially aflatoxigenic fungi could be detected. The proportion of contamination differs significantly in different regions (Table I). Soil samples from Central Transdanubia contained the lowest proportion (12.5\%) of contaminated soil samples and the highest proportion (52.9\%) was found in samples from Southern Great Plain. None of the maize samples of Northern Hungary was infected with $A$. flavus. The highest proportion $(62.6 \%)$ of contaminated maize samples was experienced in the region Central Transdanubia. However, the infection rate of $50.0 \%$ was reached or exceeded by the maize samples from the regions Central Hungary, Southern Transdanubia, Western Transdanubia, and Southern Great Plain.

In 2014, 118 soil and the same number of maize samples were analyzed for the presence of the fungi. Member(s) of Aspergillus section Flavi could be isolated from 19 (16.1\%) soil samples and $41(34.7 \%)$ maize samples. The fungi could be isolated from both soil and maize samples of six maize fields, further 13 soil and 35 maize samples contained the propagula of the fungi. Soil and maize samples of 64 sites were found to be free of the propagula of the fungi. The lowest level (soil: $10.0 \%$, maize: $10.0 \%$ ) of the contaminated samples was experienced in the region

Table I. Number (ratio) of soil and maize samples contaminated with Aspergillus strains of section Flavi in the regions of Hungary in 2013 and 2014

\begin{tabular}{|c|c|c|c|c|c|c|}
\hline \multirow[b]{3}{*}{ Region } & \multicolumn{3}{|c|}{2013} & \multicolumn{3}{|c|}{2014} \\
\hline & \multirow{2}{*}{$\begin{array}{l}\text { Soil and } \\
\text { maize } \\
\text { samples }\end{array}$} & \multicolumn{2}{|c|}{ Positive sample } & \multirow{2}{*}{$\begin{array}{c}\text { Soil and } \\
\text { maize } \\
\text { samples }\end{array}$} & \multicolumn{2}{|c|}{ Positive sample } \\
\hline & & Soil & Maize & & Soil & Maize \\
\hline Central Hungary & 6 & $1(16.7 \%)$ & $3(50.0 \%)$ & 9 & $3(33.3 \%)$ & $6(66.7 \%)$ \\
\hline Central Transdanubia & 8 & $1(12.5 \%)$ & $5(62.5 \%)$ & 11 & $2(18.2 \%)$ & $2(18.2 \%)$ \\
\hline Northern Great Plain & 13 & $2(15.4 \%)$ & $3(23.1 \%)$ & 26 & $3(11.5 \%)$ & $11(42.3 \%)$ \\
\hline Northern Hungary & 11 & $2(18.2 \%)$ & $0(0.0 \%)$ & 10 & $1(10.0 \%)$ & $1(10.0 \%)$ \\
\hline Southern Great Plain & 17 & $9(52.9 \%)$ & $10(58.8 \%)$ & 28 & $5(17.9 \%)$ & $10(35.7 \%)$ \\
\hline Southern Transdanubia & 10 & $4(40.0 \%)$ & $5(50.0 \%)$ & 19 & $3(15.8 \%)$ & $3(15.8 \%)$ \\
\hline Western Transdanubia & 13 & $2(15.4 \%)$ & $7(53.8 \%)$ & 15 & $2(13.3 \%)$ & $8(53.3 \%)$ \\
\hline Total & 78 & $21(26.9 \%)$ & $33(42.3 \%)$ & 118 & $19(16.1 \%)$ & $41(34.7 \%)$ \\
\hline
\end{tabular}


Northern Hungary. The fungi occurred in the highest rate (soil: 33.3\%, maize: $66.7 \%$ ) in the region Central Hungary.

\section{Strain determination}

Colonies of the 114 strains were yellow-green after a 7-day incubation at $26^{\circ} \mathrm{C}$, but the color of the colonies of four strains was found to be greyish green. Several isolates produced dark sclerotia. After the microscopic observation, it could be concluded that the conidiophores of the strains were hyaline and roughened, and the globose to subglobose vesicles were often biseriate, but heads with only phialides were also common. Conidia were globose to subglobose and finely rough-walled.

According to the sequence analysis of their partial calmodulin gene, all isolates proved to belong to the species A. flavus (99\%-100\% sequence similarities to strain CBS $100927^{\mathrm{T}}$, accession number: KJ175534), except the four ones of darker colony which were identified as A. parasiticus $(99 \%-100 \%$ sequence similarities to strain CBS $100926^{\mathrm{T}}$, accession number: KJ175553).

\section{Aflatoxin-producing ability of strains}

The ranges of induction factor of aflatoxigenic A. flavus strains are shown in Table II. The SOS chromotest indicated genotoxic response (IF $>1.5$ ) in case of $50(45.5 \%)$ of the tested 110 A. flavus strains. Strains isolated in 2013 from soil and maize samples contained aflatoxigen strains in the ratio of $21.1 \%$ and $15.6 \%$, respectively. These ratios significantly increased (to $50.0 \%$ and $78.0 \%$ ) in the case of the strains isolated in 2014.

The results of the SOS chromotest and that of HPLC showed high correlation $\left(R^{2}=0.89\right)$. The amounts of $\mathrm{AFB}_{1}$ produced by the seven strains (having IF value between 1.51 and 4.49 ) ranged from 1.00 to $56.0 \mathrm{mg} / \mathrm{kg}$. (All of the tested

Table II. Number of aflatoxigenic Aspergillus flavus strains isolated from the soil and maize samples collected in 2013 and 2014, based on the genotoxic results of SOS chromotest

\begin{tabular}{lccc}
\hline \multicolumn{2}{c}{ Strain isolated } & $\begin{array}{c}\text { Range of induction } \\
\text { factor (IF) }\end{array}$ & $\begin{array}{c}\text { Number of aflatoxigenic } \\
\text { A. flavus strains }\end{array}$ \\
\hline in & from & $1.55-2.74$ & 4 \\
2013 & Soil & $1.51-2.96$ & 5 \\
& Maize & $1.54-4.49$ & 9 \\
& Soil & $1.80-5.04$ & 32 \\
\hline
\end{tabular}


Table III. Aflatoxin production ( $\mathrm{mg} / \mathrm{kg}$ ) of the Aspergillus parasiticus strains

\begin{tabular}{ccccccc}
\hline Strain & Origin & $\Sigma \mathrm{AF}$ & $\mathrm{AFB}_{1}$ & $\mathrm{AFB}_{2}$ & $\mathrm{AFG}_{1}$ & $\mathrm{AFG}_{2}$ \\
\hline Pf054 & Soil, 2013 & 15.8 & 2.35 & 0.19 & 12.4 & 0.84 \\
Pf079 & Soil, 2013 & 62.7 & 41.6 & 2.34 & 17.8 & 0.99 \\
Pf148 & Maize, 2013 & 14.0 & 2.36 & 0.32 & 10.2 & 1.16 \\
Pf425 & Soil, 2014 & 20.4 & 12.9 & 1.08 & 6.04 & 0.36 \\
\hline
\end{tabular}

strains produced at least tenfold more $\mathrm{AFB}_{1}$ than $\mathrm{AFB}_{2}$ and none of them produced $\mathrm{AFG}_{1}$ or $\mathrm{AFB}_{2}$.) Thus genotoxic response indicated by the SOS chromotest was indeed caused by $\mathrm{AFB}_{1}$.

Aflatoxin-producing abilities of the four A. parasiticus strains were also measured. All the $A$. parasiticus strains produced not only aflatoxin $\mathrm{B}_{1}$ and $\mathrm{B}_{2}$, but also aflatoxin $\mathrm{G}_{1}$ and $\mathrm{G}_{2}$ detected with HPLC (Table III).

The presence of three aflatoxin biosynthesis genes, the norsolorinic acid reductase encoding gene nor-1, the sterigmatocystin O-methyltransferase encoding gene omt-1, and the regulatory gene afR was detected by PCR. All the three genes could be amplified in the case of 74 (64.9\%) strains. The nor-1 gene was the most, while aflR the less representative between the three tested genes.

After comparing results on aflatoxin biosynthesis genes and SOS chromotest, it was found that the strains whose genome lacks at least one of the three analyzed aflatoxin biosynthesis genes did not manifest genotoxicity, so presumably did not produce aflatoxin, and most strains which contained the regulatory and the two structural genes of aflatoxin production were able to manifest the genotoxicity of aflatoxin. Interestingly, in spite of the presence of the three genes, some strains were found to be non-aflatoxin producer according to the SOS chromotest.

\section{Aflatoxigenic strains in maize fields in Hungary}

The presence of aflatoxin-producing Aspergillus strains in 2013-2014 in Hungary is shown in Figure 1. Aflatoxigenic Aspergillus strains were isolated from all the seven regions of Hungary. By 2014, the aflatoxigenic A. flavus had appeared in the region Northern Hungary. The highest rate $(20.0 \%)$ of aflatoxigenic Aspergillus strains in the soil samples was found in the Central Hungarian region. Concerning maize samples, region Western Transdanubia contained the propagula of aflatoxin-producing Aspergillus strains in the highest rate, but similarly high rates $(20 \%-23 \%)$ were experienced in the maize samples of the regions Central Hungary, Southern Great Plain, and Northern Great Plain. A. parasiticus strains were found in the soil of the regions Southern Great Plain and Southern Transdanubia and in a maize sample of the region Western Transdanubia. 


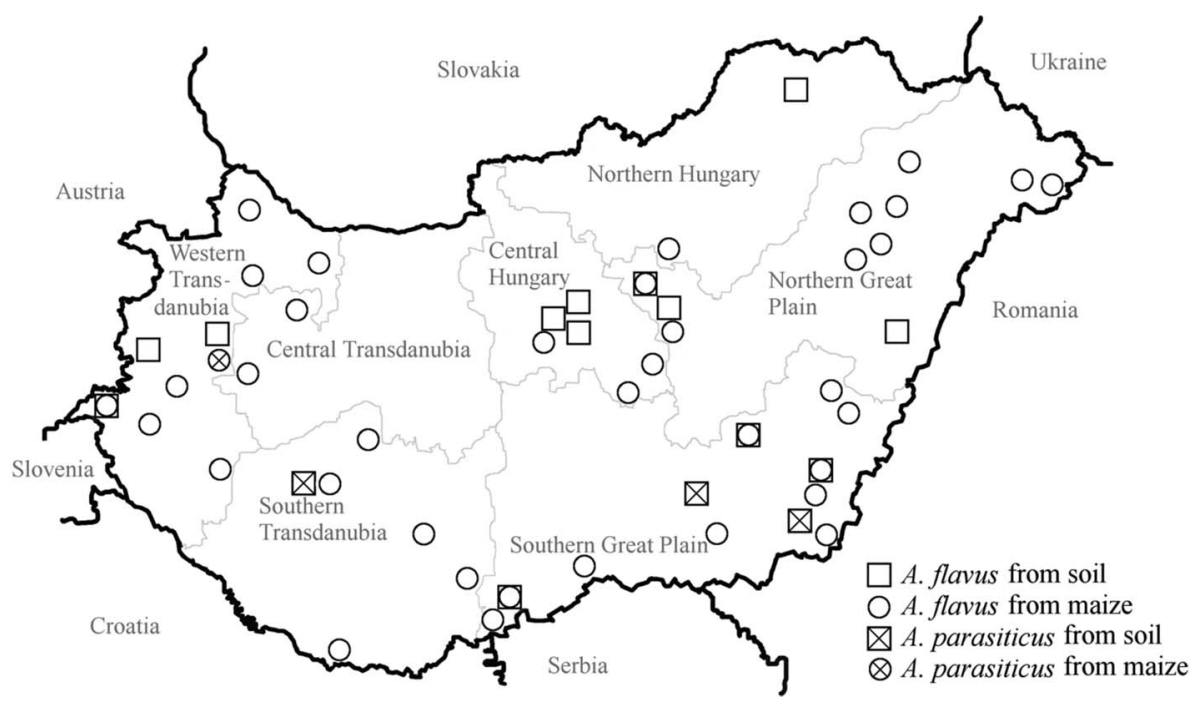

Figure 1. Distribution of aflatoxin-producing Aspergillus strains in Hungary, 2013-2014. (Only those sites are indicated where aflatoxigenic strains were found.) Soil and maize samples that contained aflatoxigenic Aspergillus strain are indicated by squares and circles, respectively

\section{Discussion}

The occurrence of species belonging to Aspergillus section Flavi and aflatoxin-producing potential of these fungi was unexplored in Hungarian (and in most European) soil. The important goals of the present work were to investigate the presence of these fungi not only in the kernels but also in the soil of maize fields and to determine their ability to produce aflatoxin by molecular methods and to confirm the aflatoxin production by biological and analytical methods.

Soil and maize samples of all the regions of Hungary (in different proportions) contained propagula of the members of Aspergillus section Flavi. The occurrence of fungi belonging to Aspergillus section Flavi in soil had a lower rate than in maize in both years. The presence of fungi, apparently because of their low quantity, could not be proved by culturing from soil in some occasions, but an enrichment of their propagula in maize kernels could be manifested. Though some factors may favorably affect the growth of molds during the transport and storage time, it can be considered that the maize crop for food and feed was infected already in the field.

Ninety-six percent of the strains isolated from Hungarian maize fields belonged to A. flavus, and the rest $4 \%$ to A. parasiticus. These results are in 
agreement with a previous work which studied Aspergillus section Flavi strains isolated in 2003-2004 in northern Italy [17]. The presence of $A$. parasiticus has been reported for decades in several countries, especially in America and Asia [30-33], and recently it was detected in wheat in Slovakia [34], and in indoor air in Croatia [35]. However, regarding the appearance of $A$. parasiticus in maize, it is the first data from Central Europe.

Although the ratio of the presence of Aspergillus section Flavi was found to be lower in 2014 than in 2013, a greater proportion of the strains isolated in 2014 were able to produce aflatoxin than the isolates of 2013. It can be supposed that aflatoxigenic Aspergillus are more competitive than strains not able to produce toxins. Influence of weather conditions on the ratio of $\mathrm{AFB}_{1}$-producing strains is considered more probable. According to the report of Hungarian Meteorological Service (http://www.met.hu/en/eghajlat/magyarorszag_eghajlata/eghajlati_ visszatekinto/elmult_honapok_idojarasa/), the summer of 2013 was warm and dry, which could induce maize stress and promote fungal infection, while that of 2014 broke the series of drought and hot summers. Heat wave and scorching heat were not experienced and more precipitation occurred than in a usual summer. However, such rainy summers used to be cooler and the weather of July 2014 was nearly tropic-like, which favors the aflatoxin biosynthesis.

The aflatoxin-producing ability of isolated strains varied widely which is in agreement with other reports [36-39]. None of the tested strains produced more $\mathrm{AFB}_{2}$ than $\mathrm{AFB}_{1}$ which is in accordance with Giorni et al. [17]. However, two of the $A$. parasiticus strains synthesized more $\mathrm{AFG}_{1}$ than $\mathrm{AFB}_{1}$.

As the majority ( $>90 \%$ ) of $A$. parasiticus strains are known as aflatoxin producers $[40,41]$ and all the four strains from Hungary were proved to be aflatoxigenic, occurrence of this species brings about the risk of aflatoxin contamination of maize in this country. Due to the ability of producing $\mathrm{AFG}_{1}$ and $\mathrm{AFG}_{2}$, beside $\mathrm{AFB}_{1}$ and $\mathrm{AFB}_{2}$, this risk can increase.

\section{Conclusions}

Contrary to the fact that aflatoxins have rarely been detected in feeds and foods in Hungary, our results demonstrated that aflatoxigenic A. flavus strains were presented in maize fields of all the seven regions of Hungary. Moreover, $A$. parasiticus strains have appeared in the soil at the regions of Southern Great Plain and Southern Transdanubia and even in a maize sample of the region Western Transdanubia. Occurrence of $A$. parasiticus among the aflatoxigenic fungi in Hungary is a noticeable result, since its appearance in maize kernels in Central Europe has not been reported. All the A. parasiticus isolates were able to 
synthesize not only aflatoxin $B_{1}$ and $B_{2}$, but also aflatoxin $G_{1}$ and $G_{2}$. Thus, regular examination of feed and food for aflatoxins, mainly after a warm and droughty summer, is essential for food safety.

\section{Acknowledgements}

This work was supported by KTIA_AIK_12-1-2013-0017 project and Research Centre of Excellence - 1476-4/2016/FEKUT project. We are grateful to KITE Agricultural Service and Trade Limited Liability Company for the soil and maize samples.

\section{Conflict of Interest}

The authors declare no conflict of interest.

\section{References}

1. Samson, R. A., Visagie, C. M., Houbraken, J., Hong, S.-B., Hubka, V., Klaassen, C. H. W., Perrone, G., Seifert, K. A., Susca, A., Tanney, J. B., Varga, J., Kocsubé, S., Szigeti, G., Yaguchi, Y., Frisvad, J. C.: Phylogeny, identification and nomenclature of the genus Aspergillus. Stud Mycol 78, 141-178 (2014).

2. Raper, K. B., Fennell, D. I.: The Genus Aspergillus. Williams and Wilkins, Baltimore, 1965, pp. 1-686.

3. Smith, J. E., Moss, M. O.: Mycotoxins: Formation, Analysis and Significance. John Wiley and Sons, Chichester, 1985, pp. 1-148.

4. Campbell-Platt, G., Cook, P. E.: Fungi in the production of foods and their ingredients. J Appl Bacteriol 18, 117S-131S (1989).

5. Varga, J., Frisvad, J. C., Samson, R. A.: A reappraisal of fungi producing aflatoxins. World Mycotoxin J 2, 263-277 (2009).

6. Blount, W. P.: Turkey "X" disease. J Br Turkey Fed 9, 55-58 (1961).

7. Asao, T., Buchi, G., Abdel-Kader, M., Chang, S., Wick, E., Wogan, G. N.: Aflatoxins B and G. J Am Chem Soc 85, 1706-1707 (1963).

8. Horn, B. W., Greene, R. L., Sobolev, V. S., Dorner, J. W., Powell, J. H., Layton, R. C.: Association of morphology and mycotoxin production with vegetative compatibility groups in Aspergillus flavus, A. parasiticus, and A. tamarii. Mycologia 88, 574-587 (1996).

9. IARC (International Agency for Research on Cancer): Some Naturally Occurring Substances: Food Items and Constituents, Heterocyclic Aromatic Amines and Mycotoxins, Vol. 56. IARC, Lyon, France, 1993, p. 362.

10. Betts, W. B., Dart, R. K.: Initial reactions in degradation of tri- and tetrameric lignin-related compounds by Aspergillus flavus. Mycol Res 92, 177-181 (1989). 
11. Cotty, P. J., Cleveland, T. E., Brown, R. L., Mellon, J. E.: Variation in polygalacturonase production among Aspergillus flavus isolates. Appl Environ Microbiol 56, 3885-3887 (1990).

12. Long, K., Ghazali, H. M., Ariff, A., Man, Y. C., Bucke, C.: Substrate preference of mycelium-bound lipase from a strain of Aspergillus flavus link. Biotechnol Lett 20, 369-372 (1998).

13. Olutiola, P. O.: Cellulase enzymes in culture filtrates of Aspergillus flavus. Trans Br Mycol Soc 67, 265-268 (1976).

14. Klich, M. A.: Biogeography of Aspergillus species in soil and litter. Mycologia 94, 21-27 (2002).

15. Horn, B. W.: Ecology and population biology of aflatoxigenic fungi in soil. J Toxicol Toxin Rev 22, 351-379 (2003).

16. Halt, M., Klapec, T., Subaric, D., Macura, M., Bacani, S.: Fungal contamination of cookies and the raw materials for their production in Croatia. Czech J Food Sci 22, 95-98 (2004).

17. Giorni, P., Magan, N., Pietri, A., Bertuzzi, T., Battilani, P.: Studies on Aspergillus section Flavi isolated from maize in northern Italy. Int J Food Microbiol 113, 330-338 (2007).

18. Borisova, L., Tasheva, Y., Sertova, N.: Investigation on the contamination of wheat and maize with Aspergillus flavus and determination of its toxicological properties to produce aflatoxins. Vet Med 12, 60-63 (2008).

19. Tabuc, C., Marin, D., Guerre, P., Sesan, T., Bailly, J. D.: Molds and mycotoxin content of cereals in southeastern Romania. J Food Prot 72, 662-665 (2009).

20. Streit, E., Naehrer, K., Rodrigues, I., Schatzmayr, G.: Mycotoxin occurrence in feed and feed raw materials worldwide: Long-term analysis with special focus on Europe and Asia. J Sci Food Agric 93, 2892-2899 (2013).

21. Baranyi, N., Kocsubé, S., Kiss, N., Palágyi, A., Varga, M., Tóth, B., Varga, J.: Identification of potential mycotoxin producing fungi on agricultural products in Hungary and Serbia. Acta Biol Hung 58, 167-170 (2014).

22. Richard, J. L., Bhatnagar, D., Peterson, S., Sandor, G.: Assessment of aflatoxin and cyclopiazonic acid production by Aspergillus flavus isolates from Hungary. Mycopathologia 120, 183-188 (1992).

23. Borbély, M., Sipos, P., Pelles, F., Győri, Z.: Mycotoxin contamination in cereals. J Agroaliment Processes Technol 16, 96-98 (2010).

24. Dobolyi, C., Sebők, F., Varga, J., Kocsubé, S., Szigeti, G., Baranyi, N., Szécsi, Á., Tóth, B., Varga, M., Kriszt, B., Szoboszlay, S., Krifaton, C., Kukolya, J.: Occurrence of aflatoxin producing Aspergillus flavus isolates in maize kernel in Hungary. Acta Aliment 42, 451459 (2013).

25. Tóth, B., Török, O., Kótai, É., Varga, M., Toldiné Tóth, É., Pálfi, X., Háfra, E., Varga, J., Téren, J., Mesterházy, Á.: Role of Aspergilli and Penicillia in mycotoxin contamination of maize in Hungary. Acta Agron Hung 60, 143-149 (2012).

26. Vanwyk, P. S., Scholtz, D. J., Los, O.: A selective medium for isolation of Fusarium spp. from soil debris. Phytophylactica 18, 67-69 (1986).

27. Hong, S. B., Go, S. J., Shin, H. D., Frisvad, J. C., Samson, R. A.: Polyphasic taxonomy of Aspergillus fumigatus and related species. Mycologia 97, 1316-1329 (2005).

28. Erami, M., Hashemi, S. J., Pourbakhsh, S. A., Shahsavandi, S., Mohammadi, S., Shooshtari, A. H., Jahanshiri, Z.: Application of PCR on detection of aflatoxinogenic fungi. Arch Razi Inst 62, 95-100 (2007). 
29. Krifaton, C., Kukolya, J., Szoboszlay, S., Cserháti, M., Kriszt, B.: Adaptation of bacterial biotests for monitoring mycotoxins. WIT Trans Ecol Environ Environ Toxicol III 132, 143154 (2010).

30. Manabe, M., Tsuruta, O.: Geographical distribution of aflatoxin-producing fungi inhabiting in Southeast Asia. Jpn Agric Res Q 12, 224-227 (1978).

31. Zummo, N., Scott, G. E.: Relative aggressiveness of Aspergillus flavus and A. parasiticus on maize in Mississippi. Plant Dis 74, 978-981 (1990).

32. Shearer, J. F., Sweets, L. E., Baker, N. K., Tiffany, L. H.: A study of Aspergillus flavus/ parasiticus in Iowa crop fields: 1988-1990. Plant Dis 76, 19-22 (1992).

33. Horn, B. W., Greene, R. L., Dorner, J. W.: Effect of corn and peanut cultivation on soil populations of Aspergillus flavus and A. parasiticus in southwestern Georgia. Appl Environ Microbiol 61, 2472-2475 (1995).

34. Dovičičová, M., Tančinová, D., Labuda, R., Sulyok, M.: Aspergillus parasiticus from wheat grain of Slovak origin and its toxigenic potency. Czech J Food Sci 30, 483-487 (2012).

35. Baranyi, N., Despot, D. J., Palágyi, A., Kiss, N., Kocsubé, S., Szekeres, A., Kecskeméti, A., Bencsik, O., Vágvölgyi, C., Klarić, M. Š., Varga, J.: Identification of Aspergillus species in Central Europe able to produce G-type aflatoxins. Acta Biol Hung 66, 339-347 (2015).

36. Joffe, A. Z.: Aflatoxin produced by 1626 isolates of Aspergillus flavus from groundnut kernels and soils in Israel. Nature 221, 492 (1969).

37. Cotty, P. J.: Aflatoxin-producing potential of communities of Aspergillus section Flavi from cotton producing areas in the United States. Mycol Res 101, 698-704 (1997).

38. Abbas, H. K., Weaver, M. A., Zablotowicz, R. M., Horn, B. W., Shier, W. T.: Relationships between aflatoxin production and sclerotia formation among isolates of Aspergillus section Flavi from the Mississippi Delta. Eur J Plant Pathol 112, 283-287 (2005).

39. Lai, X., Zhang, H., Liu, R., Liu, C.: Potential for aflatoxin $B_{1}$ and $B_{2}$ production by Aspergillus flavus strains isolated from rice samples. Saudi J Biol Sci 22, 176-180 (2015).

40. Bennett, J. W., Christensen, S. B.: New perspectives on aflatoxin biosynthesis. Adv Appl Microbiol 29, 53-92 (1983).

41. Schmidt-Heydt, M., Rüfer, C. E., Abdel-Hadi, A., Magan, N., Magan, R.: The production of aflatoxin $\mathrm{B}_{1}$ or $\mathrm{G}_{1}$ by Aspergillus parasiticus at various combinations of temperature and water activity is related to the ratio of aflS to aflR expression. Mycotoxin Res 26, 241-246 (2010). 